\title{
The role of cultural heritage in attracting skilled individuals
}

\author{
Mikaela Backman ${ }^{1} \cdot$ Pia Nilsson ${ }^{1}$
}

Received: 8 September 2015/Accepted: 15 November 2016/Published online: 26 November 2016

(C) The Author(s) 2016. This article is published with open access at Springerlink.com

\begin{abstract}
The purpose of this paper is to examine the role played by built heritages and cultural environments, alongside other locational factors, in explaining the growth of human capital in Sweden. We distinguish between urban, natural and cultural qualities as different sources of regional attractiveness and estimate their influence on the observed growth of individuals with at least three years of higher education during 2001-2010. Neighborhood-level data are used, and unobserved heterogeneity and spatial dependencies are modeled by employing random effects estimations and an instrumental variable approach. Our findings indicate that the local supply of built heritages and cultural environments explain a significant part of human capital growth in Sweden. Results suggest that these types of cultural heritages are important place-based resources with a potential to contribute to improved regional attractiveness and growth.
\end{abstract}

Keywords Built heritages $\cdot$ Human capital $\cdot$ Regional growth $\cdot$ Multilevel

\section{Introduction}

It is now well established that many of the key factors that drive regional growth in per capita income and employment are related to human capital and knowledge spillovers (Lucas 1988; Romer 1990). Regional economies constantly strive to strengthen their knowledge base and future growth strategies point at knowledge

Pia Nilsson

pia.nilsson@ju.se

Mikaela Backman

mikaela.backman@ju.se

1 Department of Economics, Finance and Statistics, Jönköping University, Gjuterigatan 5,

55111 Jönköping, Sweden 
and innovation as the key driving forces to achieve sustainable growth (European Commission 2010). In relation to this, there is a large focus in the literature on the role played by regional characteristics related to location-specific amenities in attracting skilled labor (cf. McGranahan 1999; Glaeser et al. 2001; Florida 2002; Clark et al. 2002; Rappaport 2007; Glaeser, and Kahn 2010; Albouy 2015). An important perspective set forth in this research is that amenities have a tendency to be income elastic, such that their demand rises with income and education (Brueckner et al. 1999; Moretti 2004; Lee 2010). This suggests that amenity valuations vary for skilled and unskilled workers in that high human capital workers likely have a stronger preference for amenities. A number of studies argue along these lines and show that natural amenities play a significant role in explaining individual location decisions, and especially of those individuals with high levels of human capital (Berry and Glaeser 2005; Brown and Scott 2012). Different types of amenities, such as favorable climate, proximity to lakes, oceans, forests and mountain areas are identified as important drivers of regional growth. ${ }^{1}$

Although the influence of natural amenities on human capital migration and regional growth is well documented in the literature, significantly less attention has been devoted to the influence of cultural heritage as a potentially important local attribute that is able to attract high-skilled labor (Moretti 2004; Falck et al. 2011). This is despite the increased focus on cultural heritage as an area of priority and as an important strategic resource with the potential to improve regional attractiveness and competitiveness (cf. Throsby 2001; Heidenreich and Plaza 2015; Barile and Saviano 2015). ${ }^{2}$ Sweden is no exception, and cultural heritage is viewed as an important local resource that can generate social and environmental benefits and contribute to community-led development. Studies that address the role played by listed buildings and cultural heritage sites on various types of economic indicators tend to be case studies that focus on certain types of cultural heritages or specific regions (e.g., Bedate et al. 2004; Ruijgrok 2006; Bowitz and Ibenholt 2009; Lazrak et al. 2014). One obvious limitation of such approaches is that their results are not generalizable, but apply to the specific region in focus. This paper contributes to the literature by addressing the role played by listed buildings and cultural environments in attracting high-skilled individuals across the whole Swedish geography and over time. Moreover, the analysis takes on an integrated approach and focuses on cultural heritage as a potentially important locational attribute alongside other key characteristics related to natural amenities, agglomeration and labor market characteristics. A distinction is made between different natural, cultural and urban qualities, and measures of local supply are constructed using georeferenced data. The study uses a spatially disaggregated approach based on neighborhood-level data from Sweden and employs a multilevel approach to account for unobserved heterogeneity and spatial dependencies. The presence of unobserved heterogeneity is a problem that inevitably arises in the analysis of locational factors and a

\footnotetext{
1 See for example Deller et al. (2001), Partridge and Rickman (2003), Kim et al. (2005) and Ferguson et al. (2007).

2 See also 'Conclusions on cultural heritage as a strategic resource for a sustainable Europe' adopted by the Council of the European Union on 20 May 2014 and complements the European Commission Communication 'Towards an integrated approach to cultural heritage for Europe,' published in July 2014.
} 
particular concern in this study is that cultural amenities may not be exogenously determined in the same way as natural amenities (Falck et al. 2011). In particular, since their demand rises with income and education, there is a possibility that cultural heritages are, in part, caused by regional economic growth and market size effects. To overcome these potential endogeneity problems and identify a relationship between cultural amenities and the spatial concentration of highskilled labor, we employ multilevel random effects estimations with instruments in the form of clustered centered means (Skrondal and Rabe-Hesketh 2004; Snijders and Berkhof 2008). With the intention to gain a deeper understanding of the contribution of cultural heritage in attracting skilled individuals, we also investigate whether the associations differ between urban and rural regions. The authors are unaware of any similar approaches in the literature. A line of argument that follows through this analysis is that amenity-led regional growth may not be a one-size-fitall solution and that regions may have varying potential when it comes to exploiting amenities depending on their size (McGranahan et al. 2011; Dissart and Marcouiller 2012). In order to study regional heterogeneity in the outcomes, we create interaction terms by using the amenity variables and an urban-rural taxonomy that reflect regional size and commuting patterns in Sweden. Using this approach, we find support for the importance of built heritages and cultural environments in explaining the local growth of skilled individuals in Sweden; we also find significant differences in the outcomes over the urban-rural range. Among the tested amenities, we find that it is profoundly cultural heritages that are scale driven, e.g., that have a larger effect in urban compared to rural areas.

\section{Background and theoretical framework}

Some of the early explanations for regional growth evolved around natural resources and transportation systems that influenced firms to locate in certain regions. Since around 1980, a new economy has emerged that is largely focused on technology and service-intensive sectors. This has increased the importance of cognitive skills and brought a larger focus on consumption-driven locational factors (Andersson and Beckmann 2009). As a result, many of the earlier explanations have lost their significance as primary locational attractors and it is now acknowledged that many of the key factors that drive regional growth in per capita income and employment are related to agglomeration and to the physical and ecological characteristics of an area that make it attractive (McGranahan 1999; Kim et al. 2005; Partridge et al. 2008; Glaeser and Gottlieb 2009). In this framework, we will draw attention to three principal perspectives set forth in research on the determinants of human capital migration and regional growth. The first two perspectives centers on the positive agglomeration externalities connected to the clustering of firms and the knowledge interconnections and externalities that arise from concentrations of highly educated individuals. The third perspective focus on regional attributes, such as natural and cultural amenities that make areas more desirable places to live and work in. The amenity perspective bears some resemblance with agglomeration economies in that some of these amenities may be 
affected by market size effects (population growth or rising income), while others will be fairly unaffected (Rickman and Rickman 2011). Natural and cultural amenities do also differ as local attributes in the sense that they have elements of local public goods and are maintained by the government.

\subsection{Agglomeration economies and urban amenities}

Agglomeration economies and the related concept of urban amenities are commonly pointed out as a key drivers of regional growth (Glaeser et al. 2001; Duranton and Puga 2004; Rosenthal and Strange 2008). In theory, there are various channels through which agglomeration may influence the location decisions of individuals and firms. Studies that focus on the later tend to emphasize that agglomeration economies benefiting colocated firms (Porter 2000; Parr 2002). In this view, agglomeration is closely associated with localization or 'Marshallian' economies that arise from colocation between firms within the same industry. Firms that colocate can benefit from sharing (e.g., of fixed costs, inputs and customers), matching (e.g., of workers with relevant skills), and learning due to knowledge accumulation and spatial spillovers (Duranton and Puga 2004). This view dates back to Marshall (1920), who argued that colocation is able to spur economic activity, which increases growth both in the sector and the region as a whole. The type of agglomeration economies that arise as a result of knowledge spillovers is, however, somewhat different compared to the 'Marshallian' in that it refers to a pure externality that is bounded in space (Jaffe et al. 1993; Breschi and Lissoni 2009). In the view that agglomeration is a result of knowledge interconnections, others have also pointed at the importance of industrial diversity as a source of knowledge spillovers and clustering, commonly referred to as Jacobs's externalities (Glaeser et al. 1992).

Another strand of the literature focuses on the location decisions of individuals, rather than firms and use the concept of urban amenities to signify the type of agglomeration externalities that make cities desirable places to work and live in (cf. Andersson 1985; Quigley 1998; Glaeser et al. 2001; Florida 2002; Clark et al. 2002). This literature is highly influenced by the work of Glaeser et al. (2001) and Florida (2002) and their idea of urban amenities as significant attractors of skilled and creative workers. Studies that follow along the line of Florida (2002) tend to argue for an understanding of agglomeration based on individuals and their knowledge characteristics, rather than the characteristics of firms. Accordingly, the so-called creative workers have locational preferences for different types of amenities or quality-of-life attributes, e.g., esthetics, culture, lifestyle, consumption possibilities and natural amenities. Although this theory has gained widespread popularity among policy makers, it has also been questioned on various grounds including its originality (Rausch and Negrey 2006).

\subsection{Natural and cultural amenities}

Amenities have long been seen as a central part in theories on urban growth and in explaining individual location patterns. Since the work of Yang and Fujita (1983), 
there has emerged a growing literature that focuses on location patterns and the formation of the urban spatial structure resulting from interactions between natural and cultural amenities and agglomeration (Wu and Plantinga 2003; Irwin and Bockstael 2001; Chen and Rosenthal 2008; Wang and Wu 2010). Brueckner et al. (1999) present a theoretical framework on the role played by different types of amenities in explaining location patters of high income earners. They identify three categories: (1) natural amenities (climate, topographical features, rivers, coastline, etc.), (2) historical amenities (cultural infrastructure from past eras in terms of monuments, historical buildings and architecture) and (3) urban amenities (restaurants, theaters, shops). While the first two categories are seen as largely exogenous, urban amenities are seen as endogenous and dependent on current economic conditions and income levels (Brueckner et al. 1999, p. 4). In their model, location by income depends on the spatial distribution of exogenous amenities such as water access, topography or historical amenities. Their analysis shows that when the urban center has a strong advantage over the suburbs in exogenous amenities, and when the valuation of such amenities rises with income, high-income households are likely to cluster in central locations. They also conclude that this effect occurs regardless of the presence of endogenous amenities, e.g., restaurants, theatres and other urban amenities that depend on current economic conditions. What follows from this outline is that there exist a number of potentially important locational characteristics that are able to attract high-skilled labor, not only in terms of urban and natural qualities, but also in terms of tangible and intangible cultural qualities. Andersson (2006) refers to physical cultural capital as a form of infrastructure that is able to ensure the durability and sustainability of cities. Throsby (2001) interprets cultural heritages as local public goods that generate positive spillover effects through their esthetic, authentic and historical values, which are intrinsic to their location.

An important perspective set forth in prior research is that amenities operate at different spatial ranges or limits (Cho et al. 2008). Therefore, while the benefits of some amenities attenuate slowly in distance and might be poor predictors of location choices within a region, e.g., weather conditions, other amenities are very much placed based (e.g., built amenities and landscape features) and might be critical predictors of locations choices within a region (Nilsson 2014). It has, for example, been shown that open spaces have an influence on house and land values over small geographic areas and that the effects diminish within relatively short distances (Geoghegan et al. 1997). This suggest that the contribution of amenities in attracting skilled labor may not be reflected accurately when modeled at the more aggregated regional level, which has been the dominating approach thus far. In order to account for heterogeneity among different types of place-based amenities and the local nature of their spillover effects, this study employs a spatially disaggregated approach and distinguish between three types of amenities: (1) amenities that are primarily natural, such as landscape and seascape; (2) amenities that are primarily urban and related to regional size and agglomeration; and (3) amenities which are primarily cultural, such as the local supply of built heritages (monuments, buildings and sites) and cultural environments. 
Another empirical regularity that has been identified is that amenities are valued differently depending on local and regional contexts, e.g., they tend to be driven by regional size and density (Chi and Marcouiller 2011; McGranahan and Wojan 2007). It has been found that marginal valuations of certain types of natural amenities (e.g., open spaces) are high in areas characterized by high population density and low or insignificant in areas where undeveloped lands are abundant (Bates and Santerre 2001). The implication is that amenity-led growth might not be a one-size-fit-all solution and that areas may have varying potential to exploit amenities depending on their degree of urbanization. Much of the research that focus on natural amenities and regional growth base their evidence on the type of land use patterns found in highly urbanized cities in the USA or Europe (Mieszkowski and Mills 1993; Andersson et al. 2004). Under these conditions, individuals regard high density as a dis-amenity and are willing to trade accessibility to the center against access to open space and natural amenities. As noted by many, the type of land use patterns found in most European cities are reversed and high-income households predominantly occupy centrally located expensive land (Brueckner et al. 1999). Thus, it is not evident that the same type of spatial patterns in amenity assessment exists in less urbanized regions that have relatively low density levels.

Although the local supply of natural amenities and regional attractiveness has received a lot of attention in the literature and there are many recent studies motivated by explaining their relation, there are still relatively few studies that focus on the role played by built heritages in attracting high-skilled labor. Falck et al. (2011) focus on Baroque opera houses in Germany and find that well-educated workers prefer to live geographically close to such cultural amenities. They apply an instrumental variable approach and find that it is the local level of high-humancapital employees who value proximity to a Baroque opera house and that this in turn has a positive effect on regional growth. Moro et al. (2013) analyze a related question, e.g., if housing markets reflect cultural heritage values. They estimate hedonic price equations to establish whether distance to, and density of, cultural heritage is capitalized into housing prices in Greater Dublin, Ireland. They find that some types of cultural heritage sites, such as historic buildings and memorials, provide positive spillovers to property prices and interpret these price premiums as capturing esthetic beauty. These findings support the hypotheses that high-humancapital individuals value the availability of cultural amenities (Moretti 2004); they also support the idea of cultural heritage as an important locational attribute that can increase the attractivity of an area. However, as discussed previously, most of the studies with this focus tend to be geographical delimited to the study of one specific region or to specific types of built heritages or environments. One limitation is that their results are not generalizable. ${ }^{3}$ This paper contributes to the literature by addressing the role played by listed buildings and cultural environments in attracting high-skilled individuals across the whole Swedish geography and over time. This is made possible by having access to unique spatially disaggregated data that enable us to connect the local growth of high-skilled labor with the local supply of built

\footnotetext{
${ }_{3}^{3}$ See Bedate et al. (2004), Ruijgrok (2006), Bowitz and Ibenholt (2009) or Lazrak et al. (2014) for some recent examples.
} 
heritages (e.g., historical buildings, monuments and sites), a perspective of amenityled regional growth that has received little attention in the literature. ${ }^{4}$ Although we anticipate a positive relationship between the local supply of cultural heritages and the growth of high-skilled individuals, it is also important to note that there could also be negative consequences of proximity to these heritages. For example, if they attract many tourists, congestion could prevent skilled people from locating in these areas. The expected outcome can thus be ambiguous. Besides location-specific amenities discussed above, there exist several additional factors that may influence location decisions of high-skilled individuals including the presence of institutions for higher education (Faggian et al. 2007; Faggian and McCann 2009), labor market characteristics and the demand for high-skilled labor (Andersson and Mantsinen 1980; Acs and Audrestch 1990). ${ }^{5}$

\section{Data and empirical model}

In order to address the role played by cultural heritage in attracting human capital, the empirical approach is to estimate a growth equation with change in the number of highly educated individuals as the dependent variable. There is a discussion in the literature on how to measure the skills and knowledge of individual's in the most accurate way. The traditional way is to measure human capital through the education level of the individual or the share of the population with a certain degree (Glaeser and Maré 2001). Another strand of the research emphasizes the type of work that an individual performs, i.e., the occupational status where the type of occupation that the employee performs is used as a proxy for skills (Florida 2002; Bacolod et al. 2009). ${ }^{6}$ In this paper, we follow the educational approach and measure human capital in terms of individuals with at least three years of higher education. ${ }^{7}$ A strength of this measure is that it is positively and highly correlated with intelligence and innovativeness (Parker 2004), and a weakness is the inability to capture quality differences, since a university education is assumed to have the same impact regardless of university or individual performance. To further strengthen the interpretation of our results and examine robustness, we measure growth in the level of human capital for two different time periods, the change between 2001 and 2006 or 2010. Estimating the model across these time periods allows us to determine whether temporal effects have any influence on the results because of altered macroeconomic conditions during times of recession or growth.

To address effects that are locally bounded, we use neighborhoods (Small Areas for Market Statistics, SAMS) as the unit of analysis. The rationale is that the

\footnotetext{
4 The types of cultural heritages included in the analysis are further described in Sect. 3.1.

5 For brevity, we do not discuss this literature in detail, see Baumol (1986), Anselin et al. (1997), Abramovsky et al. (2007), Faggian et al. (2007) and Abel and Deitz (2011) for studies with this focus.

6 The educational approach and creative class approach in measuring human capital are typically highly correlated (Hansen 2007; Backman 2014).

7 It should be noted that this does not mean that they have a Bachelor's degree per se, even though most individuals have acquired this degree.
} 

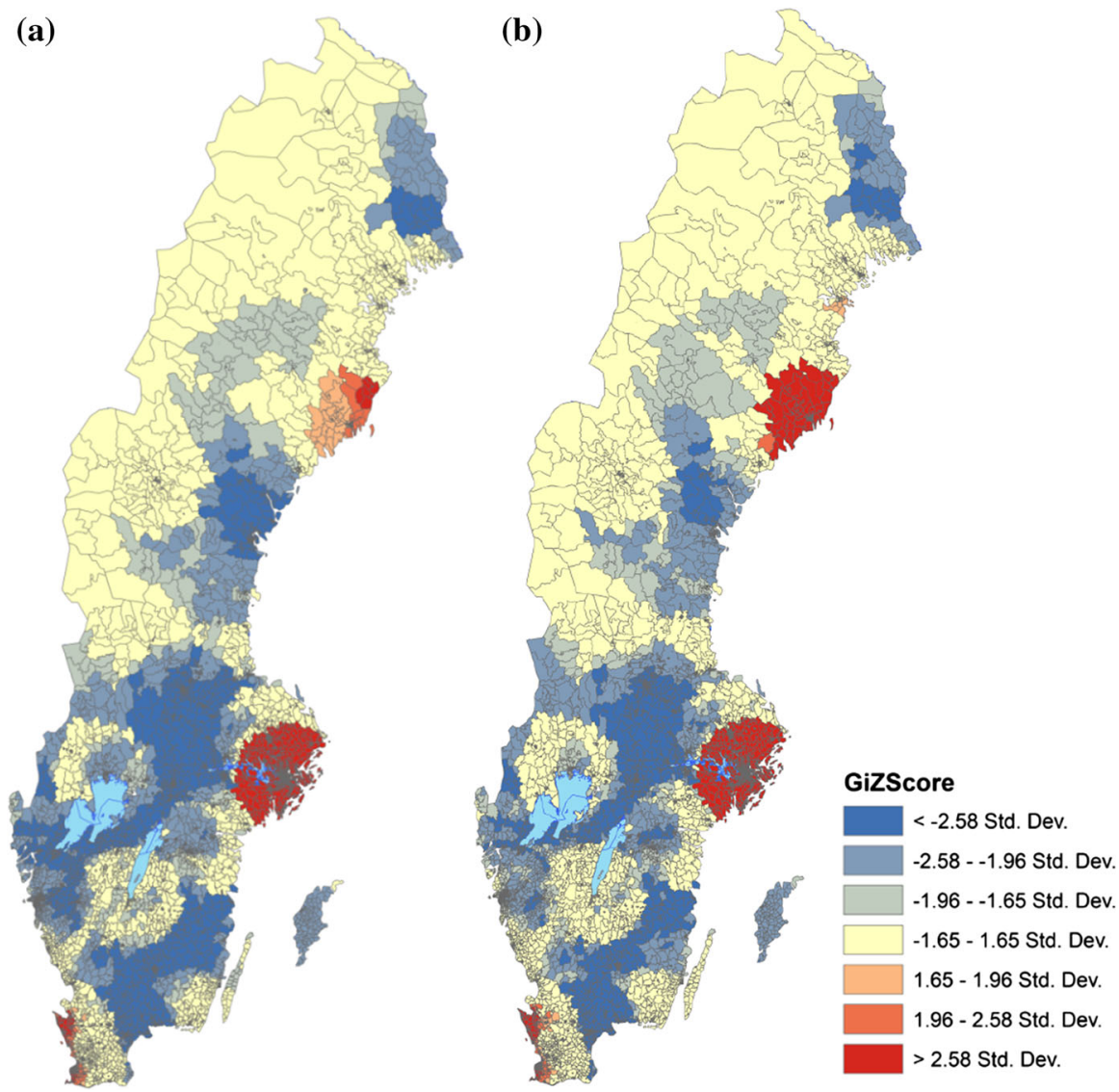

Fig. 1 Growth in high-human-capital individuals a 2000-2006, b 2000-2010

spillover effects related to knowledge and amenities have a relatively small spatial extent and decay with distance (Geoghegan et al. 1997). In Sweden, SAMS are administrative units that disaggregate municipalities into neighborhoods; there are 9200 SAMS in Sweden, and each of them has roughly 1000 inhabitants (the size and distribution of SAMS in Sweden are illustrated in Fig. 1a, b). In order to explore the dependent variable in more detail, we employ cluster analysis to identify neighborhoods with significant growth in human capital over the studied time periods. Figure $1 \mathrm{a}$, b shows returned GiZ scores from this analysis, classified using standard deviations (Getis and Ord 1996). ${ }^{8}$

SAMS in red ( $>2.58$ Std.Dev) denote those that have experienced a significant growth in human capital over the period 2001-2006 (Fig. 1a) and 2001-2010 (Fig. 1b). The figures show that growth is significantly above the national average in

\footnotetext{
8 The dependent variables used in the estimations are the raw difference in the number of high-humancapital individuals over the studied time periods. These have also been log-transformed. Estimations using the transformed dependent variable show overall insignificant results for most of the variables, which reflects the low variation in the dependent variable when using the transformed variables.
} 
neighborhoods that are located within and near the university regions Stockholm, Umeå, Malmö and Gothenburg, and these (except for Umeå) are also the most urbanized areas in Sweden. Growth is shown to be significantly below the average (in blue $<2.58 \mathrm{SD}$ ) in neighborhoods located in the rural and northern parts of the country.

\subsection{Cultural and natural amenities}

Data from three geocoded databases are used to create measures that reflect educational infrastructure, industrial composition and the supply of different types of amenities at the neighborhood level. These contain (1) data on local labor market structure and educational infrastructure obtained from Statistics Sweden, (2) naturebased amenities (climate, protected nature, open spaces, lakes and coastline) provided by The County Administrative Boards and The Swedish Meteorological and Hydrological Institute and (3) built heritages and cultural environments provided by the Swedish National Heritage Board. The amenity variables in focus are the ones that reflect local supply of cultural heritages and include built heritages (e.g., buildings, monuments and other types of physical structure that are appointed as having significant historical values) and cultural environments (e.g., cultural heritage sites that are designated as protected areas). ${ }^{9}$ Built heritages are obtained from the Data Base of Built Heritage (Bebyggelseregistret, BeBR), which is a national registry that holds information about the built heritage in Sweden. The represented built heritages range from traditional log-cabins and old industrial quarters to modern city buildings. There are around 80,000 searchable building records, with around 13,000 listed as National Monuments, Historical Buildings and Church Monuments. The content of the database is publicly available. ${ }^{10}$ Data on cultural environments are obtained from the County Administrative Boards. There are 1700 areas classified as national interests from the point of view of heritage protection, varying in their size and cultural characteristics. They include built environments, agricultural villages, city centers and mines that reflect the Swedish history and historical values from certain eras.

The variable in focus is the total number of registered built heritages and cultural environments in each neighborhood (SAMS) constructed using spatial joins (in ArcView). Since built heritages are not randomly distributed across geography and reflect places that were attractive for settlement a long time ago, the variable is weighted with population to account for this possible endogeneity bias. The hypothesis is a positive association between the local supply of cultural heritages that have an inherent historic and cultural significance and the growth of highskilled workers (Falck et al. 2011; Andersson 2006). Figure 3 in "Appendix" shows the spatial distribution of built heritages and cultural environments across Sweden, and Fig. 2 shows their number aggregated to the neighborhood level and weighted by population.

\footnotetext{
9 The Database of Built Heritage can be found at http://www.raa.se/hitta-information/ bebyggelseregistret/, and photographs from the database can be obtained by contacting the institution responsible for the information. The Historic Environmental Act (SFS 1988:950) (SWE) regulates their use.

${ }^{10}$ Updates and new entries are made continually.
} 


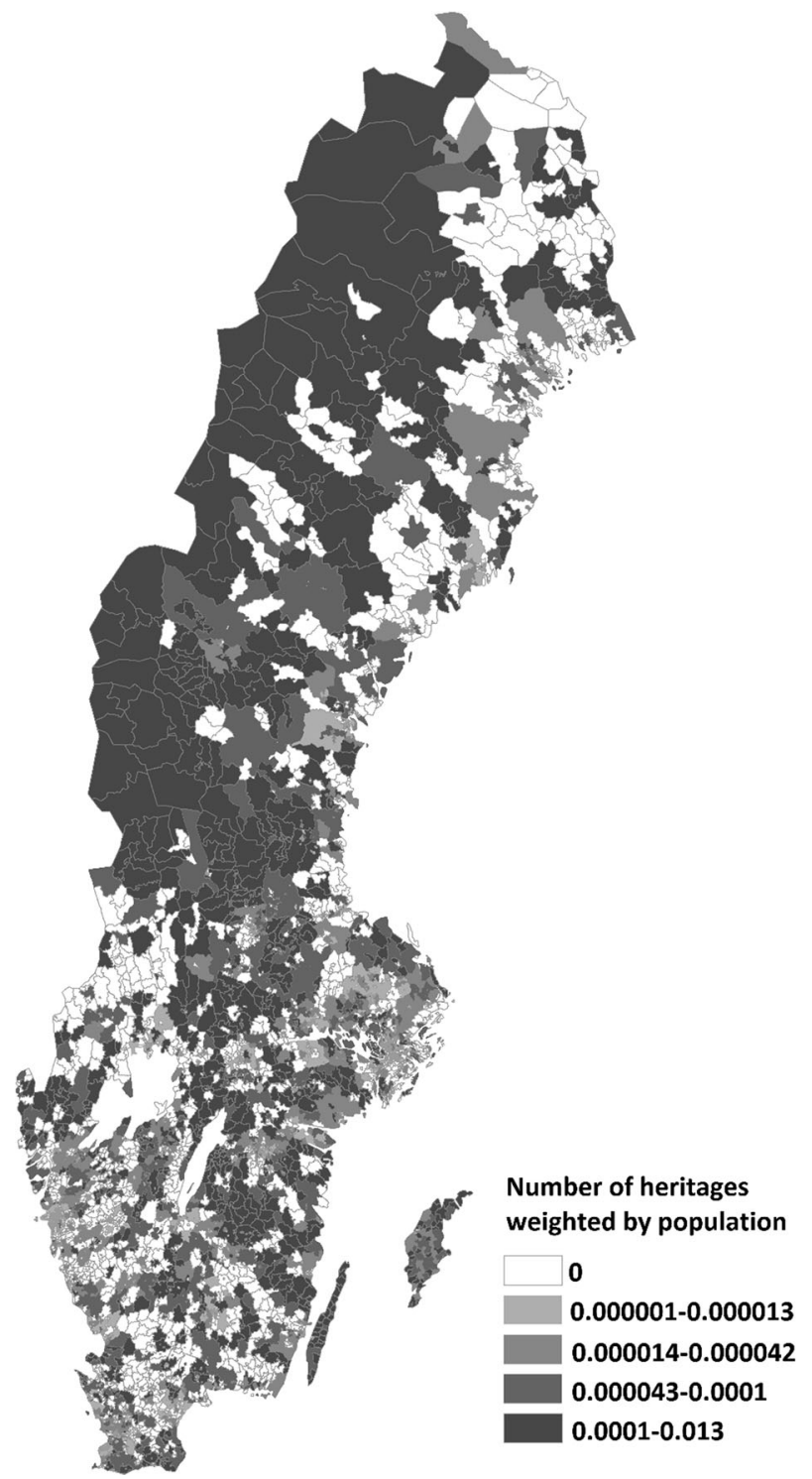

Fig. 2 Number of built heritages and cultural environments aggregated to neighborhood level (SAMS) and weighted with population

Following the outline in Brueckner et al. (1999), a distinction is made between natural and cultural amenities; seven variables are constructed to control for the local supply of nature-based amenities using the same GIS-based methodology. ${ }^{11}$ These variables measure the local supply of: (1) recreation areas and preserved open

\footnotetext{
11 These data are retrieved from the database Bebyggelseregistret (BeBR, http://www.raa.se/hittainformation/bebyggelseregistret/) and the County Administrative Boards and are georeferenced.
} 
spaces $^{12}$ (Geoghegan et al. 1997), (2) lakes, rivers, mountain and coastal areas (3) and measures of local climate (average temperature and average precipitation).

\subsection{Neighborhood characteristics related to size, education and labor market}

As discussed, a number of location-specific characteristics play an important role to attract high-skilled individuals including access to urban spaces and their concentration of private and public goods and services (Glaeser et al. 2001; Glaeser and Maré 2001). In order to capture the effects of urban amenities, we construct a gravity-type index that reflects accessibility to consumer amenities (Weibull 1980). The measure is calculated with respect to the number of employee's working within relevant service sectors (two-digit SIC code: 52-64) in the following:

$$
A_{k}^{D}=\sum_{k^{\prime}=1}^{n} D_{k^{\prime}} \exp \left\{-\lambda t_{k k^{\prime}}\right\}
$$

where $A_{k}^{D}$ denote the accessibility with regard to the number of employees that work within the service sector $D_{k^{\prime}}$ in each municipality $(k=1, \ldots, n)$. Moreover, $t_{k k^{\prime}}$ is the time distance between municipality $k$ and $k^{\prime}$. The parameter $\lambda$ measures how the accessibility responds to changes in travel time between the municipalities and can be viewed as a distance discount operator, which reduces the accessibility as travel time efforts increase. We use pre-estimated time sensitivity parameters based on observed commuting patterns in Sweden when constructing the measure (Johansson et al. 2003). This approach implies that $D_{k^{\prime}}$ reflects the mass of different types of consumer amenities that can be reached from one location taking spatial interaction costs into account. An accessibility measure of this type form has been applied in prior studies and is found to be an important factor that influences the location choice of high-skilled individuals (Backman 2014).

The presence of universities is important, not only because they produce high-human-capital individuals and employ higher-skilled labor, but also because of the resulting positive externalities to the private sector in the form of knowledge spillovers (Andersson et al. 2009; Abel and Deitz 2011). A dummy variable is therefore included to indicate if the municipality, in which the neighborhood is located, hosts a university. The ability of regions to attract human capital also depends on labor market characteristics in terms of industrial composition (Bresnahan et al. 2002; Berry and Glaeser 2005). To capture these effects, we create three variables that measure (1) the share of firms with a workforce where half of the employees have at least three years of studies at the university level, (2) the share of knowledge-intensive business firms (KIBS) and (3) the share of high technology manufacturing firms (HTMF) at the neighborhood level. Furthermore, since large regions tend to attract more high-skilled workers, we control for the size of neighborhoods in terms of population density. The regional level of human capital is also a function of the demographic structure, as human capital in many ways is a

\footnotetext{
12 Including valuable mown meadows and natural pastures, preserved forests (deciduous forests, pine forests), and green spaces. These are appointed as national areas of interest by the Swedish Environmental Protection Agency in cooperation with the county administrative boards, and The Swedish Environmental Code regulates the use of these natural areas.
} 
Table 1 Variable definitions and data sources

\begin{tabular}{|c|c|}
\hline Variable name & Variable definition \\
\hline Human capital & $\begin{array}{l}\text { Dependent variable. Difference in number of people with at least three } \\
\text { years of higher education from } 2001 \text { to } 2006 \text { or } 2010 \text {. Source: } \\
\text { Statistics Sweden }\end{array}$ \\
\hline \multicolumn{2}{|l|}{ Local level predictors } \\
\hline $\begin{array}{l}\text { Built heritages and cultural } \\
\text { environments }\end{array}$ & $\begin{array}{l}\text { Number of registered built heritages (monuments, buildings and sites) } \\
\text { and cultural environments, numbers per capita. Source: The Swedish } \\
\text { National Heritage Board }\end{array}$ \\
\hline Recreational areas & $\begin{array}{l}\text { Total land area classified as preserved natural areas that are appointed as } \\
\text { national interests from the point of view of outdoor recreation, hectares } \\
\text { per capita. Source: The County Administrative Boards }\end{array}$ \\
\hline Open spaces & $\begin{array}{l}\text { Total land area classified as preserved open spaces (mown meadows and } \\
\text { natural pastures), hectares per capita. Source: The Swedish Board of } \\
\text { Agriculture }\end{array}$ \\
\hline Lakes and rivers & $\begin{array}{l}\text { Total area of lakes and rivers, hectares per capita. Source: Swedish } \\
\text { Meteorological and Hydrological Institute }\end{array}$ \\
\hline Mountain areas & $\begin{array}{l}\text { Total area classified as mountains, hectares per capita. Source: The } \\
\text { County Administrative Boards }\end{array}$ \\
\hline Coastal areas & $\begin{array}{l}\text { Total coast area, hectares per capita. Source: The County Administrative } \\
\text { boards }\end{array}$ \\
\hline Average precipitation & $\begin{array}{l}\text { Average annual precipitation (rain and/or snow). Source: Swedish } \\
\text { Meteorological and Hydrological Institute }\end{array}$ \\
\hline Average temperature & $\begin{array}{l}\text { Average annual temperature. Source: Swedish Meteorological and } \\
\text { Hydrological Institute }\end{array}$ \\
\hline High edu. Firm & $\begin{array}{l}\text { Share of all firms with a workforce where at least } 50 \text { percent have a } \\
\text { bachelor degree or more. Source: Statistics Sweden }\end{array}$ \\
\hline KIBS & $\begin{array}{l}\text { Share of all firms that are defined as knowledge-intensive business firms, } \\
\text { KIBS, two-digit SIC code: } 72-74 \text {. Source: Statistics Sweden }\end{array}$ \\
\hline HTMF & $\begin{array}{l}\text { Share of all firms that are defined as high technology manufacturing } \\
\text { firms, HTMF, two-digit SIC code: } 22-24,30-33 \text {. Source: Statistics } \\
\text { Sweden }\end{array}$ \\
\hline Average age & Average age of inhabitants. Source: Statistics Sweden \\
\hline Population density & The total per hectare number of individuals. Source: Statistics Sweden \\
\hline \multicolumn{2}{|l|}{ Regional level predictors } \\
\hline University & $\begin{array}{l}\text { Dummy, } 1=\text { if the municipality host a higher education institution, } \\
0=\text { otherwise. Source: Statistics Sweden }\end{array}$ \\
\hline $\begin{array}{l}\text { Accessibility to urban } \\
\text { amenities }\end{array}$ & $\begin{array}{l}\text { Accessibility to employees working in the service sector (two-digit SIC } \\
\text { code: } 52-64 \text { ). Source: Statistics Sweden }\end{array}$ \\
\hline
\end{tabular}

cohort phenomenon, we therefore include the average age in the neighborhood to control for age structure.

Variables used in the empirical analysis are defined in Table 1, and summary statistics are presented in Table 2.

\subsection{Estimated model}

The data used in this study are structured as a cross-sectional dataset, and we model the growth in the number of high-skilled workers as a function of a set of initial 
Table 2 Summary statistics

\begin{tabular}{|c|c|c|c|}
\hline Variable name & Mean & Median & $\begin{array}{l}\text { Standard } \\
\text { deviation }\end{array}$ \\
\hline \multicolumn{4}{|l|}{ Dependent variable } \\
\hline $\begin{array}{l}\text { Difference in number of people with at least three years of higher } \\
\text { education from 2001-2006 }\end{array}$ & 27.97 & 14.00 & 57.76 \\
\hline $\begin{array}{l}\text { Difference in number of people with at least three years of higher } \\
\text { education from 2001-2010 }\end{array}$ & 50.33 & 25.00 & 111.31 \\
\hline \multicolumn{4}{|l|}{ Local level predictors } \\
\hline Built heritages and cultural environments & 0.008 & 0.00 & 0.10 \\
\hline Recreational areas & 104.53 & 0.00 & 1959.65 \\
\hline Open spaces & 0.14 & 0.00 & 1.28 \\
\hline Rivers and lakes & 43.77 & 0.00 & 1411.89 \\
\hline Mountain areas & $2.56 \mathrm{e}-6$ & 0.00 & $5.28 \mathrm{e}-5$ \\
\hline Coastal areas & 0.02 & 0.00 & 0.18 \\
\hline Average precipitation & 638.35 & 609.50 & 116.04 \\
\hline Average temperature & 5.76 & 6.10 & 1.97 \\
\hline High edu. firm & 0.10 & 0.07 & 0.11 \\
\hline Share KIBS & 0.12 & 0.09 & 0.12 \\
\hline Share HTMF & 0.03 & 0.00 & 0.04 \\
\hline Average age & 48.06 & 48.12 & 5.03 \\
\hline Population density & 809.16 & 562.50 & 997.82 \\
\hline \multicolumn{4}{|l|}{ Regional level predictors } \\
\hline University & 0.36 & 0 & 0.48 \\
\hline Accessibility to urban amenities & $15,129.55$ & 7074.96 & $17,464.64$ \\
\hline
\end{tabular}

conditions. Although it would have been preferable to use a panel setting, the variables that reflect the local supply of natural and cultural qualities are time invariant, implying that we need to rely on data from one year. This gives rise to the problem of unobservable heterogeneity, which is more challenging to mitigate when dealing with cross-sectional data. A concern in this study is the presence of level-2 endogeneity with regard to built heritages and cultural environments, e.g., when the local supply is influenced by factors that are common in the region (e.g., regional size and density). Although the spatial distribution of cultural heritages in Sweden does in some instances correlate with locations that have grown large and prosperous, this is not valid for the majority of cases. An indication of this is the low bivariate correlation between the local supply of built heritages and cultural environments and local population density. To account for unobserved regional heterogeneity and endogenous covariates, the empirical approach is to estimate a multilevel model where neighborhoods are nested in higher-level regional units.

The topic of endogeneity in multilevel models has been discussed in several papers (cf. Skrondal and Rabe-Hesketh 2004). Since multilevel models have at least one random intercept at each of the higher levels in the hierarchy, there is a potential for endogeneity between each of these random intercepts and the covariate in focus. A way to deal with level-2 endogeneity, in the framework of multilevel modeling, is 
to include instruments in the form of centered cluster means of the endogenous covariates (Snijders and Berkhof 2008). The rationale is that a purely within variable, e.g., a variable that vary only within clusters, is necessarily uncorrelated with any between variable, constant within the clusters (Mundlak 1978). The centered clustered mean of a level-1 covariate is thus a potential instrumental variable that is both internal and uncorrelated with the error term. A multilevel model with endogenous covariates can be expressed as:

$$
\begin{gathered}
\mathrm{HC}_{t, i j}-\mathrm{HC}_{t, i j 2001}=\alpha+X_{i j} \beta+C_{i j} \theta+\mathrm{CH}_{j} \gamma+u_{i j}+u_{j}+\varepsilon_{i j} \\
\varepsilon_{i j} \mid X_{i j} \sim N\left(0, \sigma^{2}\right)
\end{gathered}
$$

where $\mathrm{HC}$ denotes the log of the regional level of human capital, $t$ is either 2006 or 2010, neighborhoods (indexed $i$ ) are nested within a higher-level unit (municipalities $j$ ) and $j$ have a random intercept $u_{i j}$ which is assumed independent (given the covariates) and normally distributed with zero mean and constant variance (Goldstein 2011). The fixed part of the model $X_{i j}$ contains a vector of characteristics of neighborhoods, and their economic and natural characteristics hypothesized to influence their ability to attract skilled labor. Moreover, $C_{i j}$ denotes the local supply of built heritages and cultural environments, and its cluster mean centered covariate $\mathrm{CH}_{j}$ is defined as:

$$
\mathrm{CH}_{j}=H_{i j}-\bar{H}_{j}
$$

where $\bar{H}_{j}$ denotes the regional mean with regard to the supply of built heritages and cultural environments defined as:

$$
\bar{H}_{j}=\frac{i}{n_{j}} \sum H_{i j}
$$

Hence, the fixed part of the model contains variables that can be either variable within $j(i j)$ or invariant $(j)$. In the case, where the cluster sample mean coefficient $(\gamma)$ is significant, this indicates an endogeneity bias across levels. However, as this is absorbed by the instrumental variable, it does not affect the estimated coefficient of the built heritage variable $(\theta)$ (Snijders and Berkhof 2008).

The main advantage with this model is that it is able to mitigate the problems associated with unobserved heterogeneity and spatial dependencies by controlling for unmeasured heterogeneity between and within the two geographical levels. We therefore assume a higher correlation between neighborhoods within a given municipality than between and the varying intercepts can be interpreted as unobserved heterogeneity at the different levels as they induce dependence among units at the lower level in the same higher-level unit (Skrondal and Rabe-Hesketh 2004). Moreover, by estimating a growth equation where a set of initial conditions (in 2001) influence the development over the following 5 or 10 years (2006 and 2010), we mitigate the problem of reversed causality.

A useful tool in the estimation of multilevel models is the intraclass correlation coefficient (ICC), which measure the degree of correlation among observations within different levels. ICC can also be used to measure how much of the total variance in the dependent variable, in this case the growth in the level of human 
capital, that can be assigned to the different geographical levels. The ICC for the municipal level is obtained by:

$$
\mathrm{ICC}=\frac{\sigma_{j}^{2}}{\sigma_{j}^{2}+\sigma_{i}^{2}}
$$

where $\sigma^{2}$ is the variance in neighborhood $i$, and municipality $j$, respectively. The ICC ranges from zero to one: That is, it ranges from grouping bearing no information to all units in a group being identical.

\section{Regression results}

Table 3 presents the results from estimating Eq. 2 in four model specifications (A-D) including the cluster sample mean $\left(\mathrm{CH}_{j}\right)$ of the built heritages and cultural environments variable to mitigate endogeneity bias across levels. The specifications show the estimated coefficients across the time periods, and since there is a high correlation between average temperature and the variable that reflect accessibility to urban amenities, we estimate these in separate specifications. The focus in the analysis is the variable that reflects local supply of built heritages and cultural environments, alongside natural and urban qualities. Results show that the coefficient reflecting local supply of built heritage and cultural environments is positive and significant in both time periods. The positive coefficient estimate is shown to be robust to the inclusion of population density and accessibility to urban amenities and to the inclusion of the cluster mean, suggesting that it is the local supply of built heritages and cultural environments that give rise to the positive association and not regional size or density per se. For comparison, the models were also estimated both including and excluding the clustered mean of the cultural heritage variable to indicate the bias as result of omitting the endogenous covariate. Results show that built heritages and cultural environments are positively related to human capital growth in all specifications, although the coefficient has a considerably lower estimate in the model with the endogenous covariate. The centered mean of the built heritage variable is positive and significant, indicating a significant endogeneity bias across levels, absorbed by the instrumental variable (Snijders and Berkhof 2008). These results would thus lend support to the hypothesis that built heritages and cultural environments constitute important place-based resources that have the potential to improve regional attractiveness and growth in Sweden. Regarding the magnitude of the coefficient, we observe that increasing the built heritages and cultural environments with a oneunit increase would lead to an increase of approximately 50 highly educated individuals in the short run (2001-2006) and approximately 80 highly educated individuals in the medium run (2001-2010). A one standard deviation increase in the built heritages and cultural environments yields approximately a 0.09 standard deviation increase in the increase in highly skilled individuals in the short run and approximately a 0.05 increase in the medium run. ${ }^{13}$ The low coefficient can be related

\footnotetext{
13 Coefficient*standard deviation. For built heritages and cultural environments, this equals: $0.10 * 50.789=5.0879$. The dependent variable for 2001-2006 (2001-2010) has a standard deviation of $57.76(111.31)$ which gives $0.088(5.0879 / 57.76)$ and $0.045(5.0879 / 111.31)$ ratio.
} 
Table 3 Determinants of growth in the number of highly educated individuals, 2001-2006 and 2001-2010, multilevel model

\begin{tabular}{|c|c|c|c|c|}
\hline $\begin{array}{l}\text { Variables/specification } \\
\text { Local level predictors }\end{array}$ & $\begin{array}{l}\text { A } \\
2001-2006\end{array}$ & $\begin{array}{l}\text { B } \\
2001-2006\end{array}$ & $\begin{array}{l}\mathrm{C} \\
2001-2010\end{array}$ & $\begin{array}{l}\text { D } \\
2001-2010\end{array}$ \\
\hline $\begin{array}{l}\text { Built heritages and cultural } \\
\text { environments }\end{array}$ & $\begin{array}{l}50.789 * * \\
\quad(13.977)\end{array}$ & $\begin{array}{l}49.999 * * \\
\quad(13.485)\end{array}$ & $\begin{array}{r}80.306^{* *} * \\
(24.910)\end{array}$ & $\begin{array}{r}78.552 * * * \\
(23.942)\end{array}$ \\
\hline Recreational areas & $\begin{array}{r}0.001 * * * \\
(0.0001)\end{array}$ & $\begin{array}{r}0.001 * * * \\
(0.0001)\end{array}$ & $\begin{array}{r}0.001 * * * \\
(0.0002)\end{array}$ & $\begin{array}{l}0.001 * * * \\
(0.0002)\end{array}$ \\
\hline Open spaces & $0.298(0.198)$ & $0.207(0.191)$ & $0.348(0.401)$ & $0.177(0.395)$ \\
\hline Rivers and lakes & $\begin{array}{l}0.0003 * * \\
(0.0002)\end{array}$ & $\begin{array}{l}0.0003 * * \\
(0.0002)\end{array}$ & $0.001 * *(0.0002)$ & $\begin{array}{l}0.001 * * \\
(0.0002)\end{array}$ \\
\hline Mountain areas & $\begin{array}{l}3305.744 \\
(4302.979)\end{array}$ & $\begin{array}{l}826.965 \\
\quad(3410.831)\end{array}$ & $\begin{array}{r}12,369.160 \\
(8279.087)\end{array}$ & $\begin{array}{l}6249.247 \\
\quad(6463.226)\end{array}$ \\
\hline Coastal areas & $-1.149(1.433)$ & $-1.510(1.347)$ & $-3.844(3.336)$ & $-4.539(3.129)$ \\
\hline Average precipitation & $\begin{array}{c}-0.017 * * * \\
(0.006)\end{array}$ & $\begin{array}{l}-0.017 * * * \\
\quad(0.006)\end{array}$ & $\begin{array}{l}-0.034 * * * \\
\quad(0.011)\end{array}$ & $\begin{array}{c}-0.033 * * * \\
(0.011)\end{array}$ \\
\hline Average temperature & - & $\begin{array}{r}1.813^{* * * *} \\
(0.295)\end{array}$ & - & $\begin{array}{r}3.643^{* * * *} \\
(0.499)\end{array}$ \\
\hline Share High edu. Firm & $4.269(5.094)$ & $5.545(5.111)$ & $2.879(10.065)$ & $5.395(9.846)$ \\
\hline Share KIBS & $\begin{array}{l}31.908 * * * \\
(8.444)\end{array}$ & $\begin{array}{l}34.976^{* * * *} \\
\quad(9.158)\end{array}$ & $\begin{array}{r}56.618 * * * \\
(15.093)\end{array}$ & $\begin{array}{r}62.669 * * * \\
(16.186)\end{array}$ \\
\hline Share HTMF & $\begin{array}{r}33.332 * * * \\
(12.217)\end{array}$ & $\begin{array}{r}34.007 * * * \\
(12.368)\end{array}$ & $\begin{array}{r}55.933 * * * \\
(24.125)\end{array}$ & $\begin{array}{r}57.152 * * * \\
(24.357)\end{array}$ \\
\hline Average age & $\begin{array}{l}-0.444 * * * \\
\quad(0.116)\end{array}$ & $\begin{array}{l}-0.535 * * * \\
(0.118)\end{array}$ & $\begin{array}{c}-0.767 * * * \\
(0.195)\end{array}$ & $\begin{array}{c}-0.955 * * * \\
(0.217)\end{array}$ \\
\hline Population density (ln) & $\begin{array}{c}15.501 * * * \\
(1.628)\end{array}$ & $\begin{array}{c}15.419 * * * \\
(1.613)\end{array}$ & $\begin{array}{c}26.549 * * * \\
(3.358)\end{array}$ & $\begin{array}{c}26.363 * * * \\
(3.319)\end{array}$ \\
\hline \multicolumn{5}{|l|}{ Regional level predictors } \\
\hline University & $\begin{array}{c}14.261 * * * \\
(5.698)\end{array}$ & $\begin{array}{c}19.549 * * * \\
(6.986)\end{array}$ & $\begin{array}{r}26.721 * * \\
(12.779)\end{array}$ & $\begin{array}{r}39.429 * * * \\
(15.934)\end{array}$ \\
\hline Acc. urban amenities (ln) & $6.551 * * *(1.321)$ & - & $\begin{array}{c}15.102 * * * \\
(2.851)\end{array}$ & - \\
\hline Constant & $\begin{array}{c}-103.493 * * * \\
(19.487)\end{array}$ & $\begin{array}{c}-53.079 * * * \\
(9.239)\end{array}$ & $\begin{array}{c}-205.039 * * * \\
(38.846)\end{array}$ & $\begin{array}{c}-88.010 * * * \\
(16.403)\end{array}$ \\
\hline Residual variance & 2252.73 & 2254.44 & 8006.57 & 8016.31 \\
\hline Municipal variance & 157.33 & 179.39 & 712.41 & 837.76 \\
\hline Municipal-level ICC & 0.065 & 0.074 & 0.082 & 0.095 \\
\hline Likelihood ratio & 950.24 & 1073.54 & 1366.04 & 1547.50 \\
\hline AIC & 90,930 & 90,957 & 101,856 & 101,895 \\
\hline Wald $\mathrm{Chi}^{2}$ & 733.48 & 810.59 & 511.36 & 527.15 \\
\hline $\mathrm{N}$ & 8584 & 8584 & 8584 & 8584 \\
\hline
\end{tabular}

$* * *, * *, *$ Significant at 1, 5 and 10\% level, respectively. Cluster standard errors (municipalities) in parenthesis. Cluster sample means are incorporated for the variables: Built heritages and Recreational areas, these are not reported but can be requested from the authors

to the low value of the mean of the built heritages and cultural environments and a median of zero indicating that half of the neighborhoods in Sweden do not have any built heritage or cultural environments. The location of these neighborhoods is displayed in Figure 3 in the "Appendix". Although the associated increase in the 
standard deviation is small, it is important to note that having an inflow of 50 or 80 highly educated individuals, albeit over a 5- or 10-year period is for some locations seen as a drastic increase and an important input to the already existing stock of knowledge. Thus, given the size and other location-specific variables built heritages and cultural environments are factors for local policy makers to consider in attempts to increase the attractiveness of their local area.

It is also important to distinguish between natural and cultural qualities as different sources of regional attractiveness and growth. Results show that there are two types of natural qualities that are significant and robust in explaining growth in human capital, e.g., average temperature and the local supply of recreational areas. These results, along with the negative coefficient estimate for average precipitation, lend support to prior studies that use measures such as temperature or the number of sunny days to capture the breadth and diversity of amenities (Rappaport 2007). Most of the previous studies with this focus are, however, motivated by the type of climate conditions that apply in the USA with regard to regional variations in warm winters and summers. Climate conditions in Sweden are very different, and it is therefore interesting to find that average temperature plays a significant role as a local attractor of human capital.

The coefficients of the remaining natural qualities show mixed results and even though the local supply of water resources (e.g., lakes and rivers) is significant, its coefficient estimate is very small, indicating low economic significance. Turning to urban amenities, which are measured in terms of access to the total number of employees working in the service sector (Eq. 1). The estimated coefficient is positive and significant as expected, reflecting that urban amenities (in various forms) increase the number of knowledge-intensive individuals, confirmed by many others (Glaeser et al. 2001; Glaeser and Maré 2001).

The previous table focuses on how built heritages and cultural environments relate to the growth of human capital-intensive individuals in a specific location. The growth of these skilled individuals is either through migration where individuals with these characteristics decide to move to a location but can also capture if a person already living in the location has increased his/her level of education and decides to stay in the same location as before. Both aspects are important as a location is dependent on both the inflow of individuals but also that inhabitants increase their level of human capital. To further disentangle the relationship between how built heritages and cultural environments attract high-skilled individuals, we construct a dependent variable that only measures those individuals, with at least three years of higher education, that moved to another neighborhood during the period (from 2001 to 2006 or 2010). Thus, the new dependent variable only captures those that relocated during the period and is thereby more sensitive to location-specific characteristics such as built heritages and cultural environments. Results are displayed in Table 4 and show consistent estimates.

\subsection{Contextual variation and control variables}

Turning to the control variables and the contextual variation, the results show that a higher share of knowledge-intensive firms in both the business service (KIBS) and 
manufacturing sector (HTMF), i.e., the number of individuals that perform advanced and knowledge-intensive tasks is positively related to the growth of individuals with a higher education. These results are robust over the two studied time periods and to the inclusion of population density; they are also in line with prior findings stating that labor market characteristics are important determinants of local knowledge accumulation (Bresnahan et al. 2002; Berry and Glaeser 2005). Similarly, the variable indicating the presence of institutions for higher education, universities and university colleges is significant and robust. These results are intuitive considering that the presence of educational infrastructure increases the number of individuals with a higher education (supply effect); at the same time, they also give rise to a demand effect since individuals working in the university are generally highly educated. These results may also reflect that there exists a multiple effect working through other organizations and firms that are complements to universities such as Science parks and research laboratories, which also demand highly educated individuals. The link here is likely primarily via knowledge spillovers between universities and firms in the local economy as argued, for example, in Abramovsky et al. (2007). Related to the location-specific characteristics at the neighborhood level, we observe that there is a positive relationship between larger neighborhoods, in terms of population density, and the inflow of human capitalintensive individuals. It is interesting to note that the average age of the inhabitants already living in the neighborhood tend to have a discouraging effect. Given the assumption that younger and older highly educated individuals have different location preferences overall, this result can be interpreted as it is mainly younger highly educated individuals that change location and that they are attracted to neighborhoods that are overrepresented by younger individuals. The focus on how the relocation pattern differs of human capital-intensive individuals across the life-cycle is highly important but unfortunately outside the scope of this paper and is recommended for future studies.

Turning to the contextual variation, we find that the ICC for the municipality level ranges around 6-10\% across the specifications. The rather low ICC for municipalities indicates that approximately $6-10 \%$ of the total variance is explained by characteristics at the more aggregated municipality level, given the independent variable and that the remaining variation is explained by neighborhood effects. We also estimated an unconditional model, excluding the regressors, to indicate the direct effect from the two geographical levels. ${ }^{14}$ The unconditional model shows that the neighborhood level is able to explain approximately $85 \%$ of the total variance in human capital growth and that the more aggregated municipality level explains the remaining part of approximately $15 \%$. This indicates that most of the variance in the growth of highly educated individuals is captured by the variance at the local level suggesting that determinants are indeed local in nature (Cho et al. 2008).

\subsection{Regional heterogeneity in the outcomes}

The discussion so far has been focused on estimating average effects across Sweden. As discussed, regions may have varying potential when it comes to exploiting

$\overline{14}$ For brevity, we do not report these results in the paper, but they can be attained on request. 
Table 4 Determinants of inflow of number of highly educated individuals, 2001-2006 and 2001-2010, multilevel model

\begin{tabular}{|c|c|c|c|c|}
\hline $\begin{array}{l}\text { Variables/specification } \\
\text { Local level predictors }\end{array}$ & $\begin{array}{l}\text { A } \\
2001-2006\end{array}$ & $\begin{array}{l}\text { B } \\
2001-2006\end{array}$ & $\begin{array}{l}\mathrm{C} \\
2001-2010\end{array}$ & $\begin{array}{l}\text { D } \\
2001-2010\end{array}$ \\
\hline $\begin{array}{l}\text { Built heritages and cultural } \\
\text { environments }\end{array}$ & $\begin{array}{c}102.168 * * * \\
(30.389)\end{array}$ & $\begin{array}{l}100.948 * * * \\
(29.721)\end{array}$ & $\begin{array}{c}134.484 * * * \\
(42.939)\end{array}$ & $\begin{array}{c}132.294 * * * \\
(41.756)\end{array}$ \\
\hline Recreational areas & $\begin{array}{l}0.001 * * * \\
(0.0003)\end{array}$ & $\begin{array}{l}0.001 * * * \\
(0.0002)\end{array}$ & $\begin{array}{l}0.002 * * * \\
(0.0003)\end{array}$ & $\begin{array}{l}0.002 * * * \\
(0.0003)\end{array}$ \\
\hline Open spaces & $0.761(0.478)$ & $0.633(0.473)$ & $0.737(0.682)$ & $0.531(0.668)$ \\
\hline Rivers and lakes & $\begin{array}{l}0.001 * * \\
(0.0003)\end{array}$ & $\begin{array}{l}0.001 * * \\
(0.0003)\end{array}$ & $\begin{array}{l}0.002 * * * \\
(0.0003)\end{array}$ & $\begin{array}{l}0.001 * * \\
(0.0004)\end{array}$ \\
\hline Mountain areas & $\begin{array}{l}14,443.930 \\
(8785.531)\end{array}$ & $\begin{array}{l}11,008.820 \\
(7323.283)\end{array}$ & $\begin{array}{l}23,337.460 \\
(12,648.630)\end{array}$ & $\begin{array}{l}16,185.090 \\
\quad(10,180.400)\end{array}$ \\
\hline Coastal areas & $2.430(2.056)$ & $1.812(2.036)$ & $0.946(2.998)$ & $-0.008(2.837)$ \\
\hline Average precipitation & $\begin{array}{l}-0.045 * * * \\
(0.012)\end{array}$ & $\begin{array}{c}-0.043 * * * \\
(0.012)\end{array}$ & $\begin{array}{c}-0.064 * * * \\
(0.016)\end{array}$ & $\begin{array}{c}-0.060 * * * \\
(0.017)\end{array}$ \\
\hline Average temperature & - & $\begin{array}{r}3.560 * * * \\
(0.731)\end{array}$ & - & $\begin{array}{r}5.804 * * * \\
(0.907)\end{array}$ \\
\hline Share High edu. Firm & $\begin{array}{r}75.473 * * * \\
(10.668)\end{array}$ & $\begin{array}{r}76.996 * * * \\
(10.984)\end{array}$ & $\begin{array}{l}82.714 * * * \\
\quad(9.651)\end{array}$ & $\begin{array}{c}85.345 * * * \\
(9.996)\end{array}$ \\
\hline Share KIBS & $\begin{array}{r}71.893 * * * \\
(18.103)\end{array}$ & $\begin{array}{r}75.895 * * * \\
(19.330)\end{array}$ & $\begin{array}{c}110.804 * * * \\
(27.132)\end{array}$ & $\begin{array}{c}117.705 * * * \\
(28.900)\end{array}$ \\
\hline Share HTMF & $\begin{array}{r}83.530 * * * \\
(26.538)\end{array}$ & $\begin{array}{r}84.263 * * * \\
(26.724)\end{array}$ & $\begin{array}{c}114.459 * * * \\
(39.749)\end{array}$ & $\begin{array}{c}115.756 * * * \\
(39.982)\end{array}$ \\
\hline Average age & $\begin{array}{c}-1.540 * * * \\
(0.294)\end{array}$ & $\begin{array}{c}-1.670 * * * \\
(0.295)\end{array}$ & $\begin{array}{c}-1.229 * * * \\
(0.283)\end{array}$ & $\begin{array}{c}-1.458 * * * \\
(0.275)\end{array}$ \\
\hline Population density (ln) & $\begin{array}{c}32.425 * * * \\
(4.466)\end{array}$ & $\begin{array}{c}32.303 * * * \\
(4.443)\end{array}$ & $\begin{array}{c}44.299 * * * \\
\quad(6.405)\end{array}$ & $\begin{array}{c}44.073 * * * \\
(6.355)\end{array}$ \\
\hline \multicolumn{5}{|l|}{ Regional level predictors } \\
\hline University & $\begin{array}{r}40.639 * * * \\
(15.407)\end{array}$ & $\begin{array}{c}51.603 * * \\
(18.492)\end{array}$ & $\begin{array}{l}53.139 * * \\
(23.473)\end{array}$ & $\begin{array}{r}73.410 * * * \\
(28.662)\end{array}$ \\
\hline Acc. urban amenities (ln) & $\begin{array}{c}12.833 * * * \\
(2.897)\end{array}$ & - & $\begin{array}{c}23.234 * * * \\
(4.497)\end{array}$ & - \\
\hline Constant & $\begin{array}{l}-191.041 * * * \\
(47.087)\end{array}$ & $\begin{array}{c}-96.569 * * * \\
(23.479)\end{array}$ & $\begin{array}{c}-344.319 * * * \\
(73.751)\end{array}$ & $\begin{array}{l}-170.228 * * * \\
(37.167)\end{array}$ \\
\hline Residual variance & 8713.47 & 8713.13 & $18,372.82$ & $18,380.26$ \\
\hline Municipal variance & 1028.99 & 1139.05 & 2330.16 & 2680.46 \\
\hline Municipal-level ICC & 0.105 & 0.116 & 0.113 & 0.127 \\
\hline Likelihood ratio & 1944.03 & 2124.31 & 2135.62 & 2362.26 \\
\hline AIC & 102,633 & 102,653 & 109,051 & 109,082 \\
\hline Wald $\mathrm{Chi}^{2}$ & 364.43 & 360.37 & 432.85 & 486.83 \\
\hline $\mathrm{N}$ & 8584 & 8584 & 8584 & 8584 \\
\hline
\end{tabular}

$* * *, * *, *$ Significant at 1, 5 and $10 \%$ level, respectively. Cluster standard errors (municipalities) in parenthesis. Cluster sample means are incorporated for the variables: Built heritages and Recreational areas, these are not reported but can be requested from the authors 
locational amenities depending on their level of urbanization (Chi and Marcouiller 2011; McGranahan et al. 2011). Moreover, since the supply of urban amenities is driven by scale, it is necessary to study the influence of locational amenities on knowledge accumulation more in debt. The same threshold argument applies to the case of natural amenities, in that one can expect higher valuations for those natural qualities that are in high demand yet locally scarce (Bitter et al. 2007), which also relate back to the degree of urbanity. To address regional heterogeneity, we create interaction terms by focusing on the amenity variables: Recreational areas, Open spaces, and Built heritages and cultural environments. These variables are interacted with regional dummies that reflect an urban-rural taxonomy based on regional size and commuting patterns in Sweden. In particular, we use the concept of functional regions to divide the sample of neighborhoods (SAMS) into three categories:

1. SAMS in Metropolitan functional regions (Metropolitan): SAMS belong to the functional regions with the three largest cities in Sweden: Stockholm, Gothenburg, and Malmö. There are 2761 SAMS in this category.

2. SAMS in Central municipalities (Intermediate): SAMS belong to the central municipalities except the three largest cities in Sweden. The central municipalities host the largest town in each functional region, and they are relatively central locations providing higher order goods compared to peripheral municipalities, and 3306 SAMS falls into this category.

3. SAMS in Peripheral municipalities (Rural): SAMS contain the noncentral SAMS in the nonmetropolitan functional regions. This category contains 2517 SAMS.

The results including the interaction effects are presented in Table 5 in six model specifications $(\mathrm{E}-\mathrm{J})$ including the cluster sample mean for the variable that reflect local supply of cultural heritages to mitigate endogeneity bias across levels. For brevity, we only report the results of key coefficient and the full set of regression results can be obtained on request.

Starting with the dummies for each regional category $(\mathrm{E}-\mathrm{G})$, it can be observed that the metropolitan dummy is positively correlated with the growth of human capital in each SAMS (specification E). This result is confirmed in other studies showing that individuals with a higher level of human capital are attracted to large dense regions (Backman 2014). The other side of the coin is reflected in the negative influence from the dummy variable for the most rural SAMS (specification G). Although Sweden has a history of decentralization policy of institutions for higher education, no institutions were established in the most rural parts of Sweden but in the semi-rural parts. Those semi-rural locations, wherein there exist an institute of higher education, have experienced an outflow of educated individuals as graduates tend not stay in the region of study (Bjerke 2012).

The results of including interaction terms for amenities (open spaces, built heritages and cultural environments and recreation areas) show mixed results. Regarding the interaction term for the variable capturing the Built heritages and cultural environments and the regional category, a positive relationship is observed 


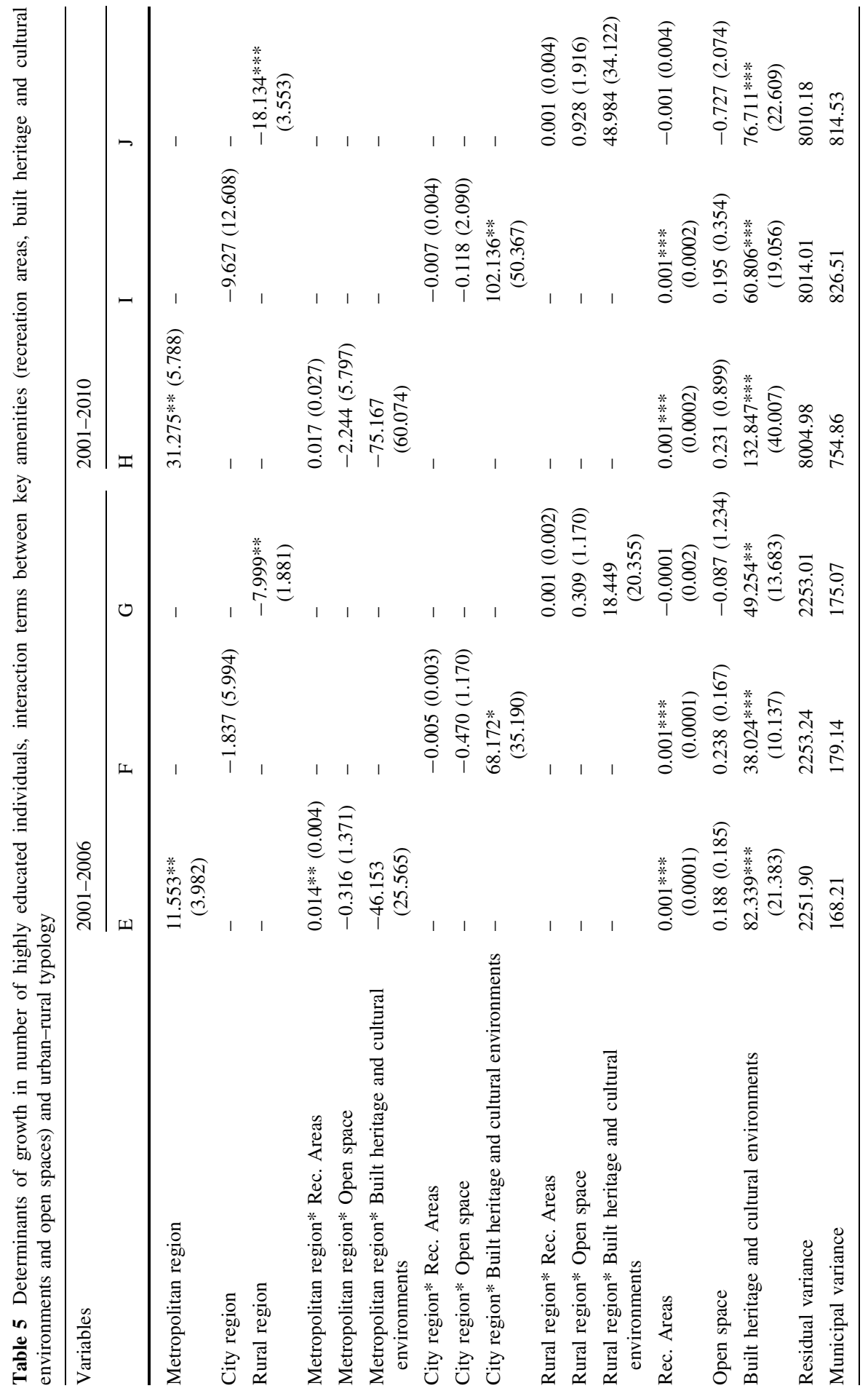




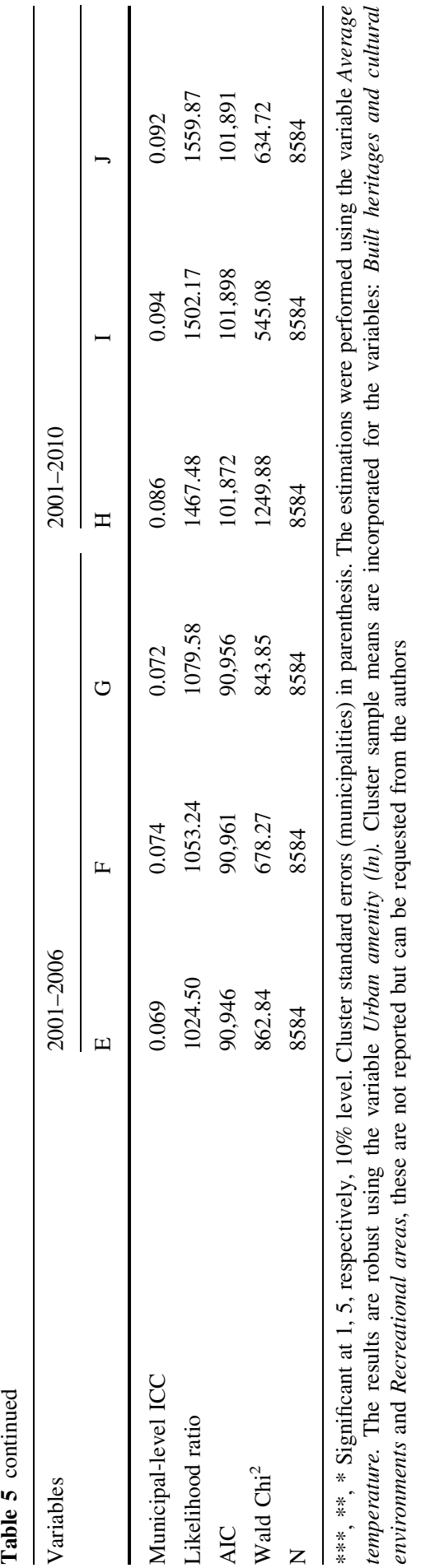


only for city municipalities. While the results show a significant and positive coefficient of the interaction term between the coefficient reflecting the local supply of recreation areas and the metropolitan dummy, we find no significant interaction effects between open space and neither of the regional categories. Nevertheless, these results are interesting as they reflect that the slope of the recreational areas coefficient, with regard to growth in human capital, changes as the level of agglomeration changes, supporting our hypotheses concerning moderation effects among the determinants. They also reflect that valuations of natural amenities (in this case recreation areas) are valued higher when located in agglomerated regions. Similar results have been found in other studies, i.e., that the supply of recreational areas is valued, marginally higher, in locations that are characterized by high population and housing densities and low, insignificant or even negative in areas where these natural types are abundant (Bates and Santerre 2001).

\section{Conclusions}

This paper examines the role played by built heritages and cultural environments, alongside other key determinants, in explaining growth in the number of highly educated individuals across neighborhood in Sweden. Built heritages and cultural environments are interpreted as local public goods in that their exterior give rise to historical amenities, which add values that are intrinsic to their location (Throsby 2001). Building on such arguments, built heritages and cultural environments are strategic resources with the potential to improve regional attractiveness and are hypothesized to play a significant role to explain growth in the level of human capital. To gain a deeper understanding of the contribution of built heritages and cultural environments for regional attractiveness, we differentiate among amenities related to urban, natural and cultural qualities (Brueckner et al. 1999) and address regional heterogeneity in their effects on human capital growth. Moreover, we emphasize that regions may have varying potential when it comes to exploiting local public goods depending on their level of urbanization (Chi and Marcouiller 2011). This argument stems from the observation that both the supply of and the demand for amenities are driven by scale, suggesting that they may create different preconditions for growth depending on the size of regions. A contribution of this paper is that the analysis takes on an integrated approach that include not only cultural heritages as potentially important locational characteristics, but several other natural and economic factors that captures important heterogeneity at the local level. Another contribution is that we can assess the role played by listed buildings and cultural environments in attracting high-skilled individuals across the whole Swedish geography and over time. This is made possible by having access to detailed georeferenced data at the neighborhood level from Statistics Sweden. The dependent variable is measured as the growth of high-skilled individuals, with at least three years of university education through migration (capturing skilled individuals that decide to move to a location), and through the observed total growth (capturing individuals already living and that decides to stay in a location after increasing their level of education). 
Our findings indicate that several local level predictors play an important role in explaining growth in human capital. Particularly, we find that the regional ability to attract high-human-capital individuals is positively related to both demand and supply factors in terms of agglomeration externalities and the presence of institutions for higher education. We also find that human-capital growth is a function of labor market characteristics in terms of the share of firms (KIBS and HTMF) that demand highskilled labor. Alongside these traditional factors, we also find that there are some natural and cultural qualities that are positively associated with growth in human capital. The local supply of built heritages (listed monuments, historical buildings and site) and cultural environments is positively associated with the growth in human capital. We also find that there are two types of natural qualities that are significant and robust in explaining growth in human capital, e.g., average temperature and the local supply of recreational areas (preserved natural areas). These results suggest that cultural heritage constitutes an important place-based resource in Sweden with the potential to improve regional attractiveness. These results also lend support to prior studies that use measures such as temperature or the number of sunny days to capture the breadth and diversity of amenities (Glaeser and Kahn 2010). Moreover, when we address interaction effects among the inputs, we find that it is only the slope of the coefficient of cultural amenities, with regard to growth in human capital, which changes as the level of agglomeration changes. This reflects that valuations of such amenities are valued higher when located in agglomerated regions. These results contribute to a deeper understanding of the role played by built heritages and cultural environments and natural amenities as drivers of change in urban and rural Sweden and ad the debate on amenity-led regional growth in important ways. Specifically, the novel finding that built heritage is an important attractor of high-skilled labor may strengthen their position in the local land use and policy decision process and provide incentives for local governments to engage in preservation efforts.

Acknowledgements This study was funded by a research grant from The Swedish National Heritage Board (dnr 3.2.2-3435-2014).

\section{Compliance with ethical standards}

Conflict of interest No conflict of interest exists for the authors.

Open Access This article is distributed under the terms of the Creative Commons Attribution 4.0 International License (http://creativecommons.org/licenses/by/4.0/), which permits unrestricted use, distribution, and reproduction in any medium, provided you give appropriate credit to the original author(s) and the source, provide a link to the Creative Commons license, and indicate if changes were made.

\section{Appendix}

See Fig. 3. ${ }^{15}$

\footnotetext{
15 The administrative border shown in the map is the county level. The administrative unit used to created aggregated share of total land at the local level is the more disaggregated SAMS level, illustrated in Fig. 2.
} 


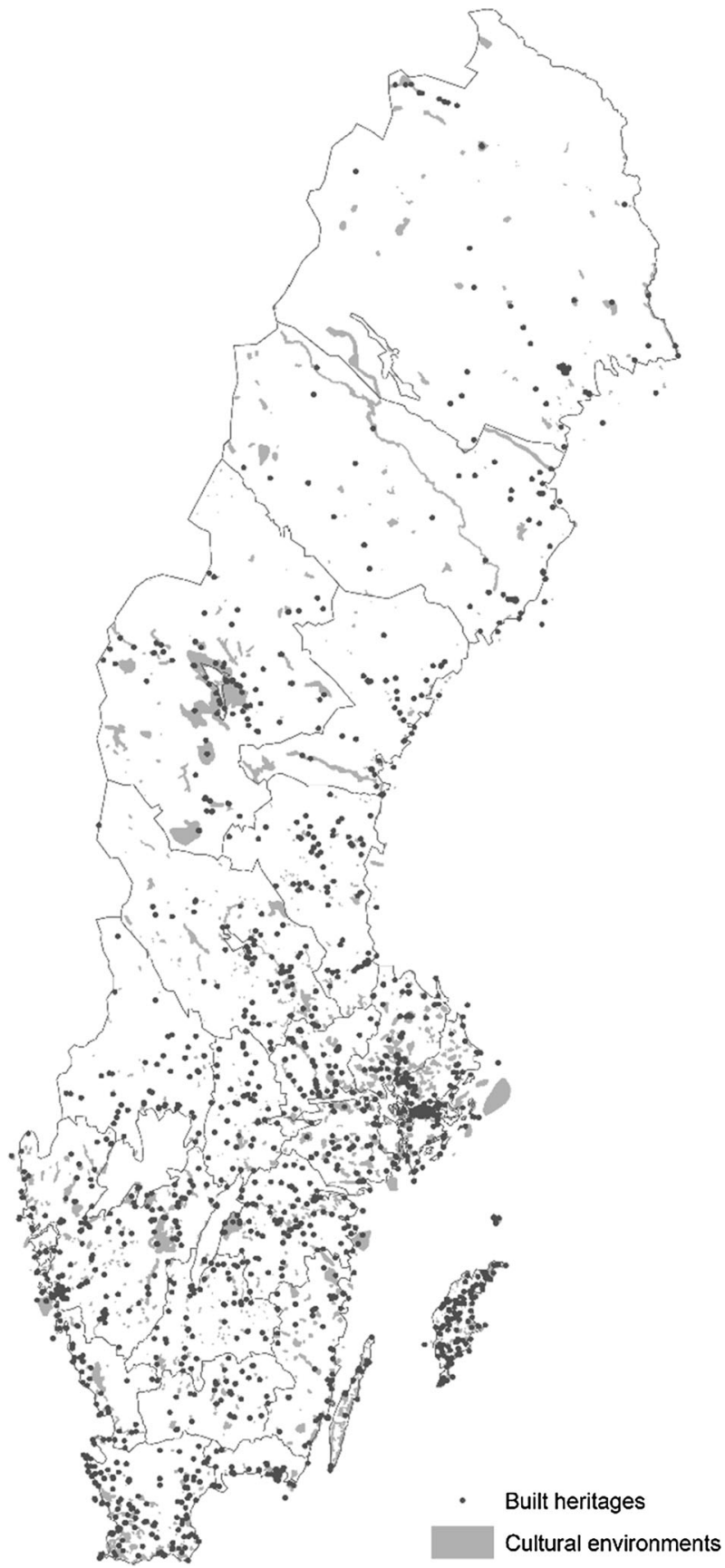

Fig. 3 Spatial distribution of built heritages and cultural environments 


\section{References}

Abel, J. R., \& Deitz, R. (2011) Do colleges and universities increase their region's human capital? In Federal Reserve Bank of New York staff report, no. 401. New York, NY: Federal Reserve Bank of New York.

Abramovsky, L., Harrison, R., \& Simpson, H. (2007). University research and the location of business R\&D. The Economic Journal, 117(519), C114-C141.

Acs, Z. J., \& Audrestch, D. B. (1990). Innovation and technological change: An international comparison. Ann Arbor: University of Michigan Press.

Albouy, D. (2015). What are cities worth? Land rents, local productivity, and the total value of amenities. Review of Economics and Statistic, 98(3), 477-487.

Andersson, A. (1985). Creativity and regional development. In Papers of the Regional Science Association (Vol. 56, No. 1, pp. 5-20). Springer.

Andersson, А. E. (2006). The economics of experiences, the arts and entertainment. Cheltenham: Edward Elgar Publishing.

Andersson, Å. E., \& Beckmann, M. J. (2009). Economics of knowledge: Theory, models and measurements. Cheltenham: Edward Elgar Pub.

Andersson, Å. E., \& Mantsinen, J. (1980). Mobility of resources, accessibility of knowledge, and economic growth. Behavioral Science, 25(5), 353-366.

Andersson, R., Quigley, J. M., \& Wilhelmsson, M. (2004). University decentralization as regional policy: The Swedish experiment. Journal of Economic Geography, 4(4), 371-388.

Andersson, R., Quigley, J. M., \& Wilhelmsson, M. (2009). Urbanization, productivity, and innovation: Evidence from investment in higher education. Journal of Urban Economics, 66(1), 2-15.

Anselin, L., Varga, A., \& Acs, Z. (1997). Local geographic spillovers between university research and high technology innovations. Journal of urban economics, 42(3), 422-448.

Backman, M. (2014). Returns to education across the urban-rural hierarchy. The Review of Regional Studies, 44(1), 33.

Bacolod, M., Blum, B. S., \& Strange, W. C. (2009). Skills in the city. Journal of Urban Economics, 65(2), 136-153.

Barile, S., \& Saviano, M. (2015). From the management of cultural heritage to the governance of the cultural heritage system. In G. M. Golinelli (Ed.), Cultural heritage and value creation (pp. 71-103). Switzerland: Springer International Publishing.

Bates, L. J., \& Santerre, R. E. (2001). The public demand for open space: The case of Connecticut communities. Journal of Urban Economics, 50(1), 97-111.

Baumol, W. J. (1986). Productivity growth, convergence, and welfare: What the long-run data show. American Economic Review, 76(5), 1072-1085.

Bedate, A., Herrero, L. C., \& Sanz, J. A. (2004). Economic valuation of the cultural heritage: Application to four case studies in Spain. Journal of Cultural Heritage, 5(1), 101-111.

Berry, C. R., \& Glaeser, E. L. (2005). The divergence of human capital levels across cities. Papers in Regional Science, 84(3), 407-444.

Bitter, C., Mulligan, G. F., \& Dallerba, S. (2007). Incorporating spatial variation in housing attribute prices: A comparison of geographically weighted regression and the spatial expansion method. Journal of Geographical Systems, 9(1), 7-27.

Bjerke, L. (2012). Knowledge flows across space and firms. Ph.D., Jönköping University, Jönköping. (JIBS Dissertation Series No. 078).

Bowitz, E., \& Ibenholt, K. (2009). Economic impacts of cultural heritage-research and perspectives. Journal of Cultural Heritage, 10(1), 1-8.

Breschi, S., \& Lissoni, F. (2009). Mobility of skilled workers and co-invention networks: An anatomy of localized knowledge flows. Journal of Economic Geography, 16(2), 1-30.

Bresnahan, T. F., Brynjolfsson, E., \& Hitt, L. M. (2002). Information technology, workplace organization, and the demand for skilled labor: Firm-level evidence. The Quarterly Journal of Economics, 117(1), 339-376.

Brown, W. M., \& Scott, D. M. (2012). Human capital location choice: Accounting for amenities and thick labor markets. Journal of Regional Science, 52(5), 787-808.

Brueckner, J. K., Thisse, J. F., \& Zenou, Y. (1999). Why is central Paris rich and downtown Detroit poor? An amenity-based theory. European Economic Review, 43(1), 91-107. 
Chen, Y., \& Rosenthal, S. S. (2008). Local amenities and life-cycle migration: Do people move for jobs or fun? Journal of Urban Economics, 64(3), 519-537.

Chi, G., \& Marcouiller, D. W. (2011). Isolating the effect of natural amenities on population change at the local level. Regional Studies, 45(4), 491-505.

Cho, S. H., Poudyal, N. C., \& Roberts, R. K. (2008). Spatial analysis of the amenity value of green open space. Ecological Economics, 66(2), 403-416.

Clark, T. N., Lloyd, R., Wong, K. K., \& Jain, P. (2002). Amenities drive urban growth. Journal of urban affairs, 24(5), 493-515.

Council of the European Union. (2014). Conclusions on cultural heritage as a strategic resource for a sustainable Europe. Education, Youth, Culture and Sport Council meeting. Brussels, 20 May 2015.

Deller, S. C., Tsai, T. H. S., Marcouiller, D. W., \& English, D. B. (2001). The role of amenities and quality of life in rural economic growth. American Journal of Agricultural Economics, 83(2), 352-365.

Dissart, J. C., \& Marcouiller, D. W. (2012). Rural tourism production and the experience-scape. Tourism Analysis, 17(6), 691-704.

Duranton, G., \& Puga, D. (2004). Micro-foundations of urban agglomeration economies. Handbook of regional and urban economics, 4, 2063-2117.

European Commission. (2010). Europe 2020: A strategy for smart, sustainable and inclusive growth: Communication from the commission. Brussels: European Commission.

European Commission. (2014). Towards an integrated approach to cultural heritage for Europe. Communication from the commission to the European parliament. The European economic and social committee and the committee of the regions. COM (2014) 477 final.

Faggian, A., \& McCann, P. (2009). Human capital and regional development. In Handbook of regional growth and development theories (pp. 133-151).

Faggian, A., McCann, P., \& Sheppard, S. (2007). Human capital, higher education and graduate migration: An analysis of Scottish and Welsh students. Urban Studies, 44(13), 2511-2528.

Falck, O., Fritsch, M., \& Heblich, S. (2011). The phantom of the opera: Cultural amenities, human capital, and regional economic growth. Labour Economics, 18(6), 755-766.

Ferguson, M., Ali, K., Olfert, M., \& Partridge, M. (2007). Voting with their feet: Jobs versus amenities. Growth and Change, 38(1), 77-110.

Florida, R. (2002). The rise of the creative class. New York: Basic Books.

Geoghegan, J., Wainger, L. A., \& Bockstael, N. E. (1997). Spatial landscape indices in a hedonic framework: An ecological economics analysis using GIS. Ecological Economics, 23(3), 251-264.

Getis, A., \& Ord, J. K. (1996). Local spatial statistics: An overview. In P. A. Longley \& M. Batty (Eds.), Spatial analysis: Modelling in a GIS environment, 374. New York: Wiley Publishers.

Glaeser, E. L., \& Gottlieb, J. D. (2009). The wealth of cities: Agglomeration economies and spatial equilibrium in the United States. Journal of Economic Literature, 47(4), 983-1028.

Glaeser, E. L., \& Kahn, M. E. (2010). The greenness of cities: Carbon dioxide emissions and urban development. Journal of Urban Economics, 67(3), 404-418.

Glaeser, E., Kallal, H., Scheinkman, J., \& Schleifer, A. (1992). Growth in cities. Joumal of Political Economy, 100, 1126-1152.

Glaeser, E. L., Kolko, J., \& Saiz, A. (2001). Consumer city. Journal of Economic Geography, 1(1), $27-50$.

Glaeser, E. L., \& Maré, D. C. (2001). Cities and skills. Journal of Labor Economics, 19(2), 316-342.

Goldstein, H. (2011). Multilevel statistical models (Vol. 922). New York: Wiley.

Hansen, H. K. (2007). Technology, talent and tolerance: The geography of the creative class in Sweden. Rapporter och Notiser 169, Department of Social and Regional Geography. Lund: Lund University.

Heidenreich, M., \& Plaza, B. (2015). Renewal through culture? The role of museums in the renewal of industrial regions in Europe. European Planning Studies, 23(8), 1441-1455.

Irwin, E. G., \& Bockstael, N. E. (2001). The problem of identifying land use spillovers: Measuring the effects of open space on residential property values. American Journal of Agricultural Economics, 83(3), 698-704.

Jaffe, A. B., Trajtenberg, M., \& Henderson, R. (1993). Geographic localisation of knowledge spillovers as evidence by patent citations. Quartely journal of Economics, 108(3), 577-598.

Johansson, B., Klaesson, J., \& Olsson, M. (2003). Commuters' non-linear response to time distances. Journal of Geographical Systems, 5(3), 315-329.

Kim, K. K., Marcouiller, D. W., \& Deller, S. C. (2005). Natural amenities and rural development: Understanding spatial and distributional attributes. Growth and Change, 36(2), 273-297.

Lazrak, F., Nijkamp, P., Rietveld, P., \& Rouwendal, J. (2014). The market value of cultural heritage in urban areas: An application of spatial hedonic pricing. Journal of Geographical Systems, 16(1), 89-114. 
Lee, S. (2010). Ability sorting and consumer city. Journal of urban Economics, 68(1), 20-33.

Lucas, R. E., Jr. (1988). On the mechanics of economic development. Journal of Monetary Economics, 22(1), 3-42.

Marshall, A. (1920). Principles of economics (8th ed.). London: Macmillan.

McGranahan, D. A. (1999). Natural amenities drive rural population change (No. 33955). United States Department of Agriculture, Economic Research Service.

McGranahan, D., \& Wojan, T. (2007). Recasting the creative class to examine growth processes in rural and urban counties. Regional Studies, 41(2), 197-216.

McGranahan, D. A., Wojan, T. R., \& Lambert, D. M. (2011). The rural growth trifecta: Outdoor amenities, creative class and entrepreneurial context. Journal of Economic Geography, 11(3), 529-557.

Mieszkowski, P., \& Mills, E. S. (1993). The causes of metropolitan suburbanization. The Journal of Economic Perspectives, 7(3), 135-147.

Moretti, E. (2004). Human capital externalities in cities. In J. V. Henderson, \& J. F. Thisse (Eds.), Handbook of regional and urban economics (Vol. 4, pp. 2243-2291). Elsevier.

Moro, M., Mayor, K., Lyons, S., \& Tol, R. S. (2013). Does the housing market reflect cultural heritage? A case study of Greater Dublin. Environment and Planning A, 45(12), 2884-2903.

Mundlak, Y. (1978). On the pooling of time series and cross section data. Econometrica, 46(1), 69-85.

Nilsson, P. (2014). Natural amenities in urban space-A geographically weighted regression approach. Landscape and Urban Planning, 121, 45-54.

Parker, S. C. (2004). The economics of self-employment and entrepreneurship. Cambridge: Cambridge University Press.

Parr, J. B. (2002). Agglomeration economies: Ambiguities and confusions. Environment and Planning A, 34(4), 717-731.

Partridge, M. D., \& Rickman, D. S. (2003). Do we know economic development when we see it? The Review of Regional Studies, 33(1), 17.

Partridge, M. D., Rickman, D. S., Ali, K., \& Olfert, M. R. (2008). The geographic diversity of US nonmetropolitan growth dynamics: A geographically weighted regression approach. Land Economics, 84(2), 241-266.

Porter, M. E. (2000). Location, competition, and economic development: Local clusters in a global economy. Economic development quarterly, 14(1), 15-34.

Quigley, J. M. (1998). Urban diversity and economic growth. The Journal of Economic Perspectives, 12(2), 127-138.

Rappaport, J. (2007). Moving to nice weather. Regional Science and Urban Economics, 37(3), 375-398.

Rausch, S., \& Negrey, C. (2006). Does the creative engine run? A consideration of the effect of creative class on economic strength and growth. Journal of Urban Affairs, 28(5), 473-489.

Rickman, D. S., \& Rickman, S. D. (2011). Population growth in high-amenity nonmetropolitan areas: What's the Prognosis? Journal of Regional Science, 51(5), 863-879.

Romer, P. M. (1990). Endogenous technological change. Journal of Political Economy, $98(5$ Part 2), S71-S102.

Rosenthal, S. S., \& Strange, W. C. (2008). The attenuation of human capital spillovers. Journal of Urban Economics, 64(2), 373-389.

Ruijgrok, E. C. M. (2006). The three economic values of cultural heritage: A case study in the Netherlands. Journal of Cultural Heritage, 7(3), 206-213.

Skrondal, A., \& Rabe-Hesketh, S. (2004). Generalized latent variable modeling: Multilevel, longitudinal, and structural equation models. Boca Raton: CRC Press.

Snijders, T. A. B., \& Berkhof, J. (2008). Diagnostic checks for multilevel models. In J. de Leew \& E. Meijer (Eds.), Handbook of multilevel analysis (pp. 77-139). New York: Springer.

Throsby, C. D. (2001). Economics and culture. Cambridge: Cambridge University Press.

Wang, C., \& Wu, J. (2010). Natural amenities, increasing returns and urban development. Journal of Economic Geography. doi:10.1093/jeg/lbq020.

Weibull, J. W. (1980). On the numerical measurement of accessibility. Environment and Planning A, 12(1), 53-67.

Wu, J., \& Plantinga, A. J. (2003). The influence of public open space on urban spatial structure. Journal of Environmental Economics and Management, 46(2), 288-309.

Yang, C. H., \& Fujita, M. (1983). Urban spatial structure with open space. Environment and Planning A, 15(1), 67-84. 